\title{
INTERTEXTUAL LITERARY SOURCES COLLECTIONS OF STORIES “LEGENDS OF THE ANCIENT KYIV" BY NATALENA KOROLEVA
}

\author{
Yulia Kovalchuk \\ Postgraduate Student at the Department of Ukrainian Literary Studies and Comparatives, \\ Zhytomyr State University named after Ivan Franko, Ukraine \\ e-mail: prujmakjula@ukr.net, orcid.org/0000-0002-1327-1358
}

\section{Summary}

The article is devoted to the consideration of literary sources from the standpoint of studying intertextuality, which allows for exploratory and literary research of the work of Natalena Koroleva, in particular collections of short stories "Legends of the ancient Kyiv".

The significant contribution of the writer is outlined, as well as a historian, ethnographer, scientist for Ukrainian literature of the twentieth century. The position of the writer as a person with Ukrainian roots is highlighted.

The article considers topical problems of intertextuality in the aspect of research of synthesis of known literary works to create a new literary canvas through reminiscences, "author's identification" and "author's model" (N. Astrakhan).

A number of well-known literary works are considered, historical events,

reflections and reflections of famous figures through the author's interpretation of Natalena Koroleva to create her own "wonder" (O. Myshanych).

Attention is paid to intertextual links in a cycle "Legends of the ancient Kyiv" various literary sources, different historical epochs, various topics, considerations of famous philosophers and cultural figures, the first historical figures, different origins of literary works. This is the identification of this collection as the pinnacle of the writer's creative work.

The author's idea of Natalena Koroleva is described on the interpretation of well-known literary monuments to emphasize the importance and originality of Ukrainian literature in the world dimension.

The importance of studying and literary research of Natalena Koroleva's works is substantiated, in particular collections of short stories "Legends of the ancient Kyiv" for the development of Ukrainian literature and culture of the Ukrainian people.

Keywords: reminiscences, intertext, interpretation, "Tale of bygone years", "Kiev-Pechersk Paterik", Bible, author's model.

\section{DOI: https://doi.org/10.23856/3847}

\section{Introduction}

The first half of the twentieth century for Ukrainian literature - it is a complex, rich and contradictory period. Writers of this era and still not all have received proper recognition in their native lands, especially those who had to emigrate. Recently, interest in the historical past has grown, the names of writers who lived and worked outside Ukraine for various reasons are returned to literature (Myshanych, 1997).

An amazing figure of Ukrainian literature of the twentieth century is Natalena Koroleva. She has a rather exotic work, which during her life did not become widely known and properly appreciated. Only recently has reader and scholarly interest in Natalena Koroleva's extraordinary prose grown, because most of her work has not been published or researched to date. 
This applies to the assembly "Legends of the ancient Kyiv" which, according to researchers, is one of the last works of the writer, the top of all her creative work, the long-awaited address of the author to Ukrainian themes through the intertextual synthesis of mythological and literary sources.

Among the scientists, who studied this work, literary critics such as R. Fedorov, V. Shevchuk, F. Pogrebennyk, O. Myshanych, O. Nakhlik, V. Antofiychuk, S. Andrusiv, K. Buslaeva, I. Golubovska, Y. Melnikova belong. They were interested in the evolution of the writer's views, problems of its narrative system, texts, features on which she built the plot. To date, there is no comprehensive study of the collection from the standpoint of using the intertext of already known literary works, which determines the relevance of this study.

Purpose of the article: explore the intertext (literary sources) of a collection of short stories "Legends of the ancient Kyiv" Natalena Koroleva.

\section{Task:}

1. Define the concept of "intertextuality" of artistic treatment of historical legends.

2. Describe historical sources - "The Tale of Past Years", "Kiev-Pechersk Paterik", chronicles, biblical stories, apocryphal tales about saints, which were used by Natalena Koroleva while working on the collection "Legends of the ancient Kyiv".

3. Analyze modern research of the author's literary heritage, in general, about the collection - in particular.

4. Identify the author as a writer of the Ukrainian diaspora.

\section{Methodology:}

The purpose, objectives of the work, the specifics of the object and subject of work led to the choice of the following methods: biographical, comparative-historical, typological, hermeneutic approach, receptive aesthetics.

\section{Natalena Koroleva and a collection "Legends of the ancient Kyiv" of short stories in scientific light}

The first half of the twentieth century is a difficult, rich and controversial period for Ukrainian literature. Writers of this era still do not all receive proper recognition in their native lands, especially those who had to emigrate. Natalia Korolyova is one of such artists. This talented, versatile, extraordinary, creative personality, half-Spanish, half-Polish, emigrant with Ukrainian roots, although she came to Ukrainian literature at a fairly mature age, and left a remarkable mark for its development and elevation to the European level.

The author herself said: "It was my husband who led me" from other distant paths to the path of Ukrainian literature" (Kovaliv, 2019).

Only in 1988 we learn about Natalia Korolyova, whose work could be the decoration of any developed European literature. Natalia Koroleva is an outstanding phenomenon in the history of Ukrainian literature. She introduced new themes from ancient and European world into Ukrainian prose (Myshanych, 1997).

Working on historical and biblical themes, the writer deliberately avoided the themes of Ukrainian history, but tried to connect the world of ancient Scythia, Russia and Ukraine with at least some invisible facets. Natalena Korolyova found in Ukrainian literature her individual artistic world, which is characterized by a symbiosis of Eastern and Western cultures, paganism and Christianity, a synthesis of Romanesque, Arabic, Greco-Roman, Byzantine and Slavic worlds (Myshanych, 1997). 
The writer used a medieval legend for a fable outline, she was not interested in the authenticity of facts and events, but "violation of deep philosophical problems", inspired by "historical metaphors" (O. Kopach).

The author interpreted well-known ancient legends and historical facts into her individual creative "microcosm".

"Legends of the ancient Kyiv" - these are twenty-five stories. Which can be divided into three structural and thematic groups: the legends of the Greek, Scythian and Slavic cycles. This is an extraordinary phenomenon in Ukrainian literature, which combines unusual adventures, wide, open intellectual horizons, noble inspiration, refined styles and a diverse synthesis of ancient and modern worldviews.

Natalena Koroleva's literary phenomenon, in our opinion, is that in her artistic search she deciphers folk and ancient mythology, Christian doctrine in order to renew the Ukrainian artistic tradition, to modernize genre forms. On the other hand, the goal was broader - to establish Ukrainian literature as a respectable component of the world literary heritage. Intellectualism, erudition and spiritual potential allowed the author to realize "an essential task in life: to create artistic values for the good of the Ukrainian nation, which was once faithfully served by members of the Dunin-Borkovsky family".

"Legends of the ancient Kyiv" became a kind of achievement of Ukrainian literature of the first half of the twentieth century, combining Ukrainian folklore, ancient myth and aesthetic thinking of Natalena Koroleva. Her literary treatment of traditional material is characterized not so much by the originality of interpretations of the Ukrainian non-fairytale epic, as by genre specifics (Riazantseva, 2003).

\section{Intertext as a key method of creating the author's "miracle world" of Natalena Koroleva}

A literary work fulfills its functional purpose only when it enters the consciousness, imagination and emotional sphere of the reader. Then it is "appropriated", which is preceded by a kind of process consisting of perception, understanding and interpretation. The known scheme "author work - reader" can be implemented in a complete form, provided a practical understanding and interpretation of the content of the work, transmitted in a certain artistic form (Bilous, 2012).

The concept of "author's interpretive model" would be perceived as more appropriate to denote the form of existence of the work in the mind of the author, a comprehensive understanding of his own work, and the phenomenon as we defined it would be more logical to call, for example, the vector program (Astrakhan, 2014).

The "author's interpretive model" emphasizes the connection between the transformation that takes place with the word in the process of artistic creation, and the specific qualities of a literary work, which give grounds to consider it as a new word (Astrakhan, 2014).

Interpretation of a literary work exists in the context of the concept of "hermeneutics". Successful interpretive images are the images of Natalena Koroleva - a writer of the Ukrainian diaspora, who with the help of rethinking, interpretation managed to create a personal "microcosm", artistic "miracle world" (O. Myshanych).

Natalena Koroleva's artistic texts open to the reader a new wider spectrum for perception and reflection. And the author comes to the aid of her favorite literary device - intertextuality.

Intertextuality is a general property of texts, expressed in the presence of links between them, through which texts (or parts of them) can in many different ways explicitly or implicitly refer to each other (Kopystianska, 2005). 
Many researchers identify "centers of intertextuality" or "centers of borrowing". As a rule, these are authors and works that are most often addressed with reminiscences. In the Western cultural tradition, there are two such mega-centers - biblical and Shakespearean. It is their motives and their interpretations that are most common in modern literature. Speaking of appealing to the cells, I mean that the authors do not always take this step consciously. It seems that usually a writer simply draws information from the general information field, without even thinking about how and from whom he borrows (Usachova, 2008).

"Legends of the ancient Kyiv" - 25 legends-stories, the writing of which was completed in the early 40-s of the last century. "Legends of the ancient Kyiv" can be divided into three thematic cycles: Scythian legends, legends of old Kiev and legends associated with the "Kiev-Pechersk Paterik". Most of their plots are familiar ("Askold's Tomb", "Perun's Curse", "Stugna", "Cyril Kozhumyak", legends about Feodosiy Pechersky, artist Alipiy) taken from Old life. Heroes of ancient mythology, Scandinavian sagas, whose actions are somehow connected with Kyiv and the Dnieper, as well as biblical figures pass through them.

These legends are rich in poetry, pure and tender love for people. In some legends in the form of an artistic story, Natalena Koroleva puts forward and reveals scientific and historical hypotheses, which are confirmed in our time.

The number of basic written sources used as proto-texts of the cycle is unlimited: "Chronicle of Rusky", Kyiv-Pechersk Paterik, "History" of Herodotus, M. Hrushevsky, "Tale of bygone years".

It is noteworthy that from these texts the author borrows plots that are codified legends and legends, while the real historical facts play the role of either the background or the basis of the side plot line. That is why written prototexts are organically combined with oral ones.

For Natalena Koroleva, intertext is a key method of creating her own interpretive "miracle world". Her focus is on man, her spiritual world. The heroes of the writer's works are extraordinary people, biblical, ancient and mythological figures, knights, inventors, united by the thirst for knowledge, the search for truths, the assertion of high ideals of the common good, brotherhood and love (Myshanych, 1997).

\section{Literary sources of the cycle "Legends of the ancient Kyiv" Natalena Koroleva's}

Through the prism of intertextuality, the world appears as a large text in which everything was once said, and the new is possible only on the principle of a kaleidoscope: mixing certain elements gives new combinations. worlds.

Natalena Koroleva used intertextual large-scale inclusions to create her artistic literary

Natalena Koroleva is an outstanding phenomenon in the history of Ukrainian literature. She introduced new themes into Ukrainian prose from the ancient and European world, successfully continuing the traditions of Lesya Ukrainka.

Working on historical and biblical themes, the writer deliberately bypassed the themes of Ukrainian history, but tried at least some invisible facets to connect the world of ancient Scythia, Rusi and Ukraine with the world of antiquity and the Middle Ages (Myshanych, 1997).

Each work by Natalena Koroleva, including the collection "Legends of the ancient Kyiv" permeated with the stream of Ukraine, its mentality and spirituality. This can be traced at all levels: from the external saturation of characters and expressions to the deepest layers of mythologists and archetypes, which are reflected in the symbols, storylines and motifs. 
Natalena Koroleva updated some prose genres in Ukrainian literature: she brought the genre of historical story to classical virtuosity, unchained the genre of literary legend (Myshanych, 1997).

With the help of intertext, she knew and felt well what she was interpreting, conveying the spirit of the depicted era from ancient times to the present.

The main milestones for Natalia Katalena to write an outstanding collection "Legends of the ancient Kyiv" became the myths of the peoples of the world, famous literary monuments and the Bible.

Let's turn to the literary sources that became objects for Natalia Korolyova for her reminiscences in the collection.

For the whole culture of Ukraine, Kievan Rus, the most important monuments of literature were and still are "The Tale of Past Years" and "Kiev-Pechersk Paterik".

Of the twenty-five legends of the cycle "Legends of the ancient Kyiv"

reminiscences from "Tales of bygone years" are found in a third of the stories.

This also applies to historical figures (Vladimir, Olga, Yaroslav, Askold and Deer), the most important historical events (the baptism of Rus and the adoption of Christianity).

"The Tale of bygone years" as a literary source can be traced in the collection in the names of legends: "From the tales of bygone years", "Vladimir's silver"; in the epigraphs to the works: "Where did it come from" ("Tavria Bay"); in events that sometimes do not coincide chronologically: Olga's visit to Constantinople and her baptism ("The Way of Salvation"); "Acne tournaments" in Kyiv ("At Yaroslav's Court"); personal testimonies-conjectures of Nestor the Chronicler that everyone in Kievan Rus walks in zlotys ("At Yaroslav's court").

Another key literary source is the "Kyiv-Pechersk Paterik" and the Bible. We repeatedly meet the author's prayers in the collection. All hagiographic legends are taken by the author for her own interpretation from the "Kiev-Pechersk Paterik".

Turning to the collection, you can find more than one hagiographic story. The following stories belong to the legends of life type: "Feast", "Funeral", "Devils", "From the tales of time". Hagiographic legends about Alypius the Icon Painter, Sergius the Martyr, Gregory the Blackhorn, the Archangel Michael, the Apostle Andrew.

The author of the Old Testament story about Cain and Abel interpreted: "You see," she says, "this is the solid proof that brotherly hatred is the most natural thing!". From whom could Cain have inherited it, when at that time there were barely four people in the world. It's not fun, it's nature, as hungry as it is, as the need for sleep. You don't even have to teach..." ("Gostina") (Soyko, 2006).

After all, the main thing for the writer was the soul of the heroes, their experiences and actions, which are worthy of praise and respect.

Folklore of any nation is a constant of literature. Natalena Korolyova did not miss various milestones of oral folk art for her intertextual inclusions in the collection precisely to emphasize the identity and importance of the Ukrainian people.

More than once in the collection we meet songs that are heard from the mouths of gods and goddesses: "You love me. I can't spin! Threads are torn, Hands are shaking, Mother dear". There is also a song that the author heard from Professor V. N. Malinin in Kyiv: "Rain is the joy of the world, Rain, God! Rain is the joy of the world, Rain-god" ("Meluzina", "On Delos").

There are motives of magic: the expulsion of demons from the body of the demon ("Guest"), "grandmother's" curses: "biscum album" (“On the Delos"), and so on.

Natalena Koroleva also interpreted the folk tale about Kirill Kozhumyak, at the same time showing the balance and wisdom, decency and justice of Vladimir ("Kirill Kozhumyak"). 
Mentioned ancient games (game with water and scales "On Delos"), rites and customs on national holidays (Christ's feast of the Savior ("Feast").

Various Old Kyiv legends about princes, the origin of glorious Kyiv families, etc. have been interpreted.

Natalena Koroleva is depicted as hesitating, warning about the resistance and anxiety about the adoption of Christianity by the with the help of the reminiscence of the well-known work "A Word about Igor's Campaign" (eclipse of the sun).

Since Oleksa Myshanych considers Natalena Koroleva to be a continuation of Lesia Ukrainka's theme, indeed, the representation of philosophical considerations, motives, and images of nature can be traced in the story "Moon Yarn" when Losna met with Abbot Anthony. Interpretation of Mavka's meeting with Lukash from "Forest Song": "My good father, my name is Losna. I am not carnal, spirit. From a country far away, the most beautiful, where the people of Rasen lived in the past. So, like this white flower, she drew a bundle of cherry blossoms, the people who called me the "goddess of the moon" blossomed and crumbled (Soyko, 2006).

Intertextual connections permeate the collection of short stories of such famous philosophers as Herodotus, Sophocles, Plato, reminiscences of the famous historical work of Mykhailo Hrushevsky "History of Ukraine", the mentioned hypotheses from the "Chronicle of Oskold", interpreted works of Silius Italicus, Stephenus Oleisus and Stefanos, the legend of St. Ambrose, the works of St. Teresa of Avila, the statement of Voltaire, the intertext of his own work "Ancestor" about the origin of the genus Lakerda.

The whole spectrum of intertextual reminiscences testifies to the intellectual perfection of Natalena Koroleva (the last story of the collection "The Godfather of Pope John" "a man who knows everything, never dies"), as well as the assertion of the Ukrainian people from ancient times by thinkers and famous figures.

\section{Conclusions}

The cycle "Legends of the ancient Kyiv" was written by Natalena Koroleva in the 1940-s and became one of the earliest Ukrainian-language works of the writer. This is indicated both by Natalena Koroleva's own testimony and by the use of stories of completely borrowed plots, which is not typical of the author's further work, as well as the author's metatext of the cycle, which is different from other works of the writer.

Synthesis of various mythological and literary sources in the collection and use of intertext as a key technique for creating your own "author's model" (N. Astrakhan) and testifies to the uniqueness of the figure of Natalena Koroleva in the history of Ukrainian literature and the uniqueness of all her work.

\section{References}

Astrakhan N. (2014). Buttya literaturnogo tvoru: analitychne ta interpretacijne modelyuvannya: monografiya [The existence of a literary work: analytical and interpretive modeling: monograph]. Kyiv: Akademvidav. 432 p. [in Ukrainian]

Bilous P. V. (2012). Interpretaciya literaturnogo tvoru [Interpretation of a literary work]. Zhytomyr: ZhSU. 140 p. [in Ukrainian]

Kovaliv Yurii. (2019). Literaturni syluety [Literary silhouettes]. Word and time. № 2. P. 69. [in Ukrainian] 
Kopystianska N. (2005). Zhanr, zhanrova sy stema u prostori literaturoznavstva [Genre, genre system in the space of literary criticism]. Kyiv: Art-Vertep. 368 p. [in Ukrainian]

Myshanych O. (1997). Dyvosvity Nataleny Korolevoyi. Povernennya [Miracles of Natalena Koroleva. Return]. 2 edition revised and supplemented. Kyiv: "Oberehy". 336 p. [in Ukrainian] Natalena Koroleva. (2006). Legendy starokyyivski [Legends of Old Kiev] / N. V. Soiko. Kyiv: Shkola. 2006. 256 p. [in Ukrainian]

Riazantseva T. (2003). Pomolytysya za dushu pysmennyci: Do 115-richchya Nataleny Korolevoyi. [Pray for the soul of the writer: To the 115-th anniversary of Natalena Koroleva]. Ukrainian language and literature in secondary schools, gymnasiums, lyceums and colleges. № 1. P. 200-203. [in Ukrainian]

Usachova K. (2008). Agiografichni ta epichni interteksty v prozi Nataleny Korolevy: avtoref. dys. kand. filol. nauk: 10.01.01 [Hagiographic and epic intertexts in the prose of Natalena Korpleva: abstr. of the dissert. of the cand. of philol. sciences. 10.01.01]. Kiev. Nat. Univ. T. Shevchenko. 16 p. [in Ukrainian] 